\title{
How real is the threat of imprisonment for environmental crime?
}

\author{
Carole M. Billiet $\cdot$ Sandra Rousseau
}

(C) Springer Science+Business Media, LLC 2011

\begin{abstract}
In this contribution, we investigate whether prison sentences for environmental crime are indeed used in practice, how they are used and whether they imply a real threat to violators. To this end we examine previous studies on the role of imprisonment and confront these models with some empirical data. The empirical application summarizes evidence from several countries, but focuses on detailed data for criminal prosecution of environmental legislation in Flanders (Belgium) between 2003 and 2007. Thus we are able to highlight some interesting policy issues and directions for future research.
\end{abstract}

Keywords Enforcement · Environmental offenses · Prison sentences · Criminal prosecution

JEL Classification K32 Environmental, health and safety law $\cdot$ K41 Litigation process - K42 Illegal behavior and the enforcement of law

\section{Introduction}

Legislation dealing with environmental protection and pollution prevention typically includes one or more sanctioning instruments to deal with breaches of its provisions. The most common of these instruments are monetary fines and prison sentences. In this contribution, we investigate whether prison sentences for

C. M. Billiet

Center for Environmental and Energy Law, Universiteit Gent, Universiteitsstraat 4,

9000 Gent, Belgium

S. Rousseau $(\bowtie)$

Faculty of Economics, HUBrussel \& Center for Economic Studies-K. U. Leuven,

Stormstraat 2, 1000 Brussel, Belgium

e-mail: Sandra.Rousseau@econ.kuleuven.be 
environmental crime are indeed used in practice, how they are used and whether they imply a real threat to violators. To this end, we investigate evidence from several countries, but focus in more detail on data concerning criminal prosecution of environmental legislation in Flanders (Belgium) between 2003 and 2007. This analysis allows us to highlight some interesting policy issues and potential areas for future research.

Since only criminal judges can impose prison sentences through court cases, we focus on the criminal sanctioning track for environmental violations and do not consider the administrative or civil track. Criminal enforcement was an unusual occurrence in environmental law until well into the $1980 \mathrm{~s},{ }^{1}$ but for the last decades it has steadily increased in frequency. For the US, for instance, O'Hear (2004) mentions that the total number of defendants prosecuted in criminal environmental cases increased by more than ten-fold between 1984 and 2001. ${ }^{2}$ Since the late 1990s, however, the total number of criminal judicial cases for environmental offenses has slowly declined in the US (Gray and Shimshack 2011). In the EU, the use of criminal enforcement has recently been reinforced by the introduction of the EU Directive 2008/99/EC on the Protection of the Environment through Criminal Law. Moreover, we take the constitutional framework as given and do not investigate the role and working of prisons. For an overview of the economics of prisons, the allocation of resources to and within prison facilities, the impact on recidivism and the role of offender rehabilitation programs, we refer to Avio (1998).

Three major justifications can be discerned for the legal imposition of penalties by an authority (see, for instance, ALRC 2002): (1) compensation for the damage caused, or restoration; (2) retribution for the violation of legal requirements; and (3) protection of third parties or society at large. Obviously, different types of penalties satisfy these three justifications to a different extent. As a case in point, prison sentences score high on protecting society, but low on compensating for the harm done. Partly for this reason, the UK Sentencing Advisory Panel, for instance, suggested that custodial sanctions should only be considered where (Environmental Audit Committee 2003): “(a) the offense is shown to have been a deliberate or reckless breach of the law, or the defendant acted from a financial motive, whether profit or cost saving; and either (b) (i) human health has been damaged or put at risk; or, (ii) the pollutant was noxious, widespread or pervasive, or liable to spread widely or have long lasting effects". So the role of prison sentences seems to be become more important as the environmental offenses become more serious.

Previous research has mentioned several reasons why non-monetary sanctions such as prison sentences can be needed for optimal enforcement of (environmental) legislation. As mentioned by Polinsky and Shavell (1984) prison sentences can be a desirable alternative to fines when the offender's wealth is limited. The wealth constraint implies that the deterrence effect of fines is limited, while imprisonment is still effective. Another motivation for the use of prison sentences focuses on the

\footnotetext{
${ }^{1}$ Firestone (2003) mentions, for instance, that the US federal government prosecuted only 25 environmental criminal cases during the 1970s.

2 In fiscal year 2002, the US Environmental Protection Agency (EPA) referred 250 matters to the Department of Justice (DOJ) for criminal prosecution, up from 31 in 1984. The total number of defendants charged rose from 36 in 1984 to 371 in 2001 (O'Hear 2004).
} 
particular need for non-monetary sanctions when fines can be passed on to customers or shareholders as just another cost of doing business (Firestone 2003). This transfer of the costs associated with environmental violations can be prevented by using non-monetary sanctions such as prison sentences. Additionally, prison terms are said to be an especially valuable sanction in attempting to control the behavior of corporate officials, "who belong to a social group that is exquisitely sensitive to status deprivation and censure" (Firestone 2003). After all, serving a prison sentences carries a moral stigma that may not be easily escaped. The major drawback of using prison sentences is the costs to government and society of building, maintaining and managing prison facilities. As an example, the direct costs of keeping one prisoner in a maximum security prison in the US are reported to cost tax payers $40,000 \$$ (Cooter and Ulen 2008) to 50,000\$ (The Economist 2010) per year.

In the next Sect. 2 we discuss some crucial insights from existing literature concerning the role of prison sentences in the enforcement of crime. Next we look at the available evidence on the use of prison sentences in practice (Sect. 3) and focus specifically on the detailed data for Flanders (Sect. 4). In Sect. 5 we look at the possible policy implications following from the observed use of prison sentences and formulate some concluding remarks.

\section{Theoretical background}

When it comes to the study of non-monetary sanctions in the (law \&) economics literature, most of the attention is given to prison sentences (see, for instance, Polinsky and Shavell 1984; Shavell 1987; Kaplow 1990; Levitt 1997; Garoupa and Klerman 2004).

The analysis of the use of prison sentences as one of several sanctioning instruments can be structured along two dimensions. Firstly, prison sentences can be used separately or simultaneously in combination with other sanctioning instruments. Thus a prison sentence can be the only sanction imposed on a convicted offender or it can be imposed simultaneously with a fine or another sanction. Secondly, prison sentences can be imposed as an effective sanction that is implemented immediately or as a suspended ${ }^{3}$ sanction to be implemented only when certain conditions are fulfilled. The use of prison sentences as an effective sanction focuses on the deterrence aspects, while a suspended sanction focuses more on prevention. Moreover, as Kennedy (2002) states “... a probationary sentence avoid[s] the morally objectionable prospect of jailing someone whose actions might not have been wrongful in the fullest sense of the word."

In general, when an offender's wealth is limited, optimal deterrence theory (e.g. Polinsky and Shavell 1984) suggests that non-monetary sanctions such as imprisonment are required. More specifically, Shavell (1985) has identified five

\footnotetext{
${ }^{3}$ Later we use the terms 'conditional' or 'probationary' as an alternative to a 'suspended' sanction, since these type of sanctions share the same basic principle, namely execution of a sanction conditional on the fulfilment of certain conditions. These conditions can however differ according to the judicial system and thus we use the terminology mentioned in the original texts when possible.
} 
factors that are relevant to the question of whether a non-monetary sanction is necessary for optimal criminal deterrence: (1) the probability of bankruptcy (2) the probability that a party will escape sanction (as this probability increases, the likelihood that the monetary sanction needed will exceed a person's assets increases); (3) the level of private benefits resulting from the offense (the higher the benefits, the greater monetary sanction needed to deter); (4) the probability that an act will cause harm; and (5) the magnitude of the harm. If these factors are sufficiently high, non-monetary sanctions may be desirable if one seeks to maximize social welfare despite the greater social costs associated with their use.

Later, explicitly taking into account public and private budget constraints, Polinsky (2006) showed that, when offenders' wealth is unobservable, it might be desirable to impose a prison sentence on low-wealth offenders in order to better deter high-wealth offenders through socially less costly fines. While Polinsky (2006) explicitly distinguished between individuals with high and low wealth levels, Levitt (1997) previously investigated individuals with a different disutility from time in jail. Levitt's main point is that the availability of fines as an alternative to imprisonment might not result in higher social welfare. This is due to his assumption that an alternative to imprisonment cannot strictly increase deterrence. On the other hand, Chu and Jiang (1993) assume that fines are proportional to the level of harm and they find that it might be desirable to deter offenders by imprisonment or by less-than-maximal fines.

Another frequently mentioned argument in favor of using prison sentences is the social stigma attached to them (see e.g. Firestone 2003). Particularly for individuals working in positions of responsibility and trust prior to conviction, the stigma of incarceration might be severe and leading to a substantial loss of future earnings (see e.g. Waldfogel 1994; Nagin and Waldfogel 1995). Also, the stigma and stress associated with incarceration can lead to considerable long term health effects (see e.g. Schnittker and John 2007).

The concept of the enforcement pyramid, introduced by Ayres and Braithwaite (1995), can also provide insight in the use of prison sentences. According to this model, violators are initially dealt with by soft enforcement instruments (such as advices and warnings) and only if those measures do not have the desired effect, more stringent instruments are used. This way the enforcing authorities climb up the pyramid until the firm or individual returns to compliance. The threat of more severe punishments, such as a prison sentence or a withdrawal of an environmental license, can be a sufficient incentive for firms and individuals to encourage them to regularize their compliance status. This threat of harsher future punishment thus increases the effectiveness of less formal, soft enforcement instruments. This model provides a broader framework to study sanctions since it explicitly allows for enforcing authorities to choose between several sanctioning instruments. The main reason for the regulator to use these escalating sanctions for persistent or repeat offenders ${ }^{4}$ is found in the costs savings associated with using cheaper instruments

\footnotetext{
${ }^{4}$ Other studies concerning harsher punishments for repeat offenders include, among others, Emons (2003, 2007), Chu et al. (2000) and Polinsky and Rubinfeld (1991). However, these studies do not explicitly analyse this topic in a framework of multiple sanctioning instruments.
} 
more often and expensive instruments less often. After all, the social costs associated with effectively implementing a prison sentence are substantially higher than those of imposing a fine or imposing a suspended prison sentence. This cost argument is reinforced by the empirical study by Cherry (2001) who provides evidence for the US that financial penalties provided a significant deterrent effect comparable to those provided by prison sentences and that the use of financial punishment can reduce criminal justice expenditures. ${ }^{5}$ Also, the cooperative attitude of firms' and individuals within the firms is likely to be higher when the regulator adopts a soft approach rather than a strict penalizing approach and this might ultimately lead to a faster resolution of the environmental compliance problem. Empirical evidence of this enforcement strategy is provided for the textile industry in Belgium by Billiet and Rousseau (2005) and for The Netherlands by Blomberg and Michiels (1997). Furthermore, a non-negligible part of violations result from a lack of information on the part of the offender (see, for instance, Heyes 1998 or Dasgupta et al. 2000). In these instances, soft enforcement instruments suffice to reduce the information gap and to induce the offender to voluntary comply with regulation. Thus, according to the concept of the enforcement pyramid, we will observe prison sentences only for persistent or repeat offenders and not for first-time offenders.

Noteworthy is that theoretical models from the (law and) economics literature do not seem to distinguish between effective and suspended prison sentences, but rather (implicitly) assume that sentences are effectively implemented when imposed. Moreover, very few studies seem to allow for the combined use of prison sentences with other sanctioning instruments. Insofar prison sentences are studied in combination with other instruments, those instruments are analyzed as substitutes rather than complements.

\section{International evidence on the use of prison sentences for environmental crime}

Empirical studies concerning prison sentences for environmental violations, however, are extremely scarce, though some exceptions exist. First we look at the evidence from the United States, next we turn to Australia and finally we discuss Europe.

\subsection{United States of America}

Three decades ago prison sentences were not used as a deterrent for environmental crime in the US. However, the role of imprisonment in environmental enforcement has evolved over time and has become increasingly important.

\footnotetext{
5 The analysis by Cherry (2001) is, however, done on an aggregate county level and measures the level of criminal activity by the index crime rate, which does not include environmental crime. The index includes seven major crimes: murder, rape, robbery, assault, burglary, larceny, and auto theft.
} 
Table 1 Environmental enforcement actions in the US (Gray and Shimshack 2011)

\begin{tabular}{|c|c|c|c|c|}
\hline & \multirow{2}{*}{$\begin{array}{l}\text { Federal and regional EPA } \\
\text { formal administrative } \\
\text { actions }\end{array}$} & \multirow{2}{*}{$\begin{array}{l}\text { Civil } \\
\text { judicial } \\
\text { cases }\end{array}$} & \multicolumn{2}{|c|}{$\begin{array}{l}\text { Criminal judicial } \\
\text { cases }\end{array}$} \\
\hline & & & Number & $\begin{array}{l}\text { Sentences } \\
\text { (in years) }\end{array}$ \\
\hline 2008 & 2,368 & 280 & 319 & 57 \\
\hline 2007 & 2,550 & 278 & 340 & 64 \\
\hline 2006 & 4,944 & 286 & 305 & 154 \\
\hline 2005 & 2,660 & 259 & 372 & 186 \\
\hline 2004 & 2,936 & 265 & 425 & 77.3 \\
\hline
\end{tabular}

In a recent overview of the effectiveness of environmental monitoring and enforcement, Gray and Shimshack (2011) discuss the formal enforcement actions taken by the US Environmental Protection Agency (EPA). As shown in Table 1, approximately $80 \%$ of these actions are administrative actions, some $9 \%$ involve civil judicial cases and some $11 \%$ are criminal judicial cases. Thus, administrative actions - ranging from telephone and letter warnings to fines-clearly represent the EPA's dominant sanctioning strategy. The role of administrative fines has grown over recent years: in 2001 some $53 \%$ of all administrative actions included a fine, while in 2008 this figure has increased to 82\% (Gray and Shimshack 2011). Moreover, as mentioned by Gray and Shimshack (2011), penalties are often large and frequently include jail time, even though the number of judicial cases is small.

Looking more closely at criminal judicial cases in the US, we find few relevant studies. Cohen (1992) provided empirical evidence on monetary sanctions as well as prison sentences imposed on over 100 US firms between 1984 and 1990. Although the evidence in Cohen (1992) is not overwhelming, the findings were consistent with the notion that imprisonment and fines are substitutes with respect to deterrence. Cohen (1992) studied practices before the US sentencing guidelines were in place and noted that most convicted defendants received probation and that, insofar punishment was inflicted, the median prison term imposed was only about 6 months. His study also suggested that individuals who falsified tests or were owners or managers of firms were more likely to receive a jail sentence when convicted.

In a more recent study, O'Hear (2004) comments on US sentencing guidelines. He notes that the guidelines nearly always mandate at least a short period of imprisonment where there has been an actual discharge of pollutants into the environment (as opposed to mere administrative, non-damaging violations). Even the discharge of a small amount of a nontoxic pollutant results in an offense which carries a presumptive term of 6-12 months in jail. In short, O'Hear (2004) concludes that the guidelines are designed to put "green-collar" offenders ${ }^{6}$ behind bars, even if only for a relatively brief period of time.

As shown in Table 2, O'Hear (2004) reports that approximately one in three sentenced environmental defendants received a prison term in US federal courts in the period 1996-2002. The length of the terms imposed is relatively short: nearly $60 \%$ are sentenced to one year or less and fewer than $10 \%$ are sentenced to more

\footnotetext{
$\overline{6}$ With 'green collar' offenders O'Hear (2004) refers to environmental offenders in a corporate context.
} 
Table 2 Environmental defendants sentenced to prison terms in US federal courts (US Sentencing Commission, O'Hear 2004)

\begin{tabular}{lcc}
\hline Fiscal year & $\begin{array}{l}\text { Sentenced } \\
\text { environmental } \\
\text { defendants }\end{array}$ & $\begin{array}{l}\text { Environmental } \\
\text { defendants receiving } \\
\text { prison sentence }\end{array}$ \\
\hline 1996 & 64 & 33 \\
1997 & 127 & 53 \\
1998 & 122 & 50 \\
1999 & 127 & 42 \\
2000 & 137 & 42 \\
2001 & 86 & 20 \\
Total & 663 & 240 \\
\hline
\end{tabular}

than 4 years. O'Hear (2004) also observes that environmental defendants seem to be treated with lenience relative to other defendants; since, over the same time period, more than $80 \%$ of all sentenced federal defendants received a prison term and less than $25 \%$ of these terms was a year or less, while more than $45 \%$ exceeded 4 years. O'Hear (2004) suggests that the fact that environmental defendants have little criminal history might be a likely explanation for the relative leniency.

Thus in the US we find no structured, aggregate information on the use of suspended versus effective sanctions nor on the simultaneous use of prison sentences with other sanctions in the (law and) economic literature, not even in the overview statistics provided by the US administration. We do find anecdotal and case-specific evidence of simultaneous use of imprisonment and other sanctions as well as the use of suspended sanctions for environmental offenses.

\subsection{Australia}

For Australia, we can only report on general sanctioning strategies and not specifically on environmental sanctioning. The Australian Law Reform Commission (ALRC 2002) found that 793, out of some 2,400 penalty provisions in federal law, had imprisonment as a sentencing option. Of those, 279 allowed imprisonment only, the remainder allowing a choice between imprisonment and a fine. The types of offenses for which only imprisonment is indicated are largely offenses which include an element of contempt (either in a court context or in the course of a regulator's investigations or hearings) and providing false or misleading information. Moreover, the commission also stressed "the importance of reserving imprisonment for only the most serious offenses, with the primary value of imprisonment arising from its perception as the ultimate sanction".

\subsection{Europe}

For the European Union in general, Faure and Heine (2005) report that fines are apparently more popular than prison sentences. Based on surveys in the different member states, they identify some possible reasons for the popularity of fines. Firstly, the quality of the offenses is mentioned: most involve minor cases and 
first-time offenders. Furthermore, environmental criminal prosecution is relatively new and there is still insufficient legal history to guide judicial decisions.

Concerning the UK criminal justice system, the Environmental Audit Committee (2003) claims that the courts in the UK are using the full range of sentencing options available to them since the sentencing profile for environmental offenses in 2002 shows that:

- 9 offenders received custodial sentences for environmental offenses $(0.58 \%)$,

- 29 offenders received community sentences for environmental offenses $(1.88 \%)$,

- 1,292 offenders were fined for environmental offenses $(83.79 \%)$, and

- 212 offenders received an absolute or conditional discharge (13.75\%).

The Committee states that the fact that courts rarely sentence towards the higher ends of their powers in respect of these offenses suggests that they consider the maxima available to provide a sufficient range for appropriate sanctioning. Finally, the UK Environment Agency (2008) reports 6 defendants with a custodial sentence (of 15.5 months on average) and 11 defendants with a suspended custodial sentence (of 38.9 months on average) in 2007. However, Ogus and Abbot (2002) mention that the UK Environment Agency seldom prosecutes environmental incidents since it only focuses on serious violations. Nonetheless it should be noted that the Agency is generally successful in those prosecutions which it does bring before the criminal courts and secures a conviction in over $95 \%$ of the prosecutions brought under waste, water and integrated pollution control. According to Ogus and Abbot (2002) the agency explicitly recognizes that adverse publicity has a significant impact on the behavior of potential offenders and may be more important than the other consequences of prosecution. For Scotland specifically, we find that at most $1 \%$ of all sentenced prisoners in custody on 30 June 2007 were related to environmental offenses according to government statistics (Scottish Government 2008).

In the Netherlands (WODC-CBS 2009) the following sanctions were imposed on environmental offenders by courts of first instance in 2008 :

- 21 offenders received only a prison sentence $(<0.5 \%)$,

- 128 offenders received a prison sentence simultaneous with another sanction $(2.6 \%)$,

- 4,426 offenders were fined $(89.6 \%)$, and

- 135 offenders received community sentences $(2.7 \%)$.

\subsection{General trends}

In general we find that imprisonment seems to be significantly more popular in criminal enforcement in the US than in Europe. Over $30 \%$ of criminal sentences include a prison sentence in the US, while in EU this percentage is significantly lower $(0.5-2.5 \%)$. In the US there is a strong reliance on administrative and civil judicial actions for environmental enforcement (Gray and Shimshack 2011). Criminal prosecution is only used in more serious cases such as persistent offenders or violations causing considerable damage to the environment or public health. This bias towards more serious crime naturally leads to a more frequent use of prison 
sentences in criminal cases. The empirical evidence for Europe shows that convicted environmental offenders are generally fined. The different studies (e.g. Faure and Heine 2005) suggest that environmental offenses are more likely to be minor offenses and that offenders in general are often first-time offenders; however, there are exceptions such as the criminal prosecution policy in the UK and possibly also in The Netherlands. The general lack of prison sentences imposed is consistent with the concept of the enforcement pyramid which advocates low frequency use of high cost stringent sanctioning instruments. The use of imprisonment as ultimum remedium in environmental sanctioning can be found throughout the different legislatures. Moreover, in the UK and possibly also in the Netherlands, criminal enforcement is treated as an ultimum remedium in prosecution as well.

Also, we observe that-at least in some countries-prison sentences are rarely the only sanction imposed on a particular offender in practice. As a rule, in countries such as Belgium and The Netherlands, fines or other financial sanctions are simultaneously imposed.

\section{Detailed evidence for flanders}

In order to study het role of imprisonment and document the criminal decision process with regard to environmental crime in Flanders, ${ }^{7}$ we investigate judgments by seven Courts of First Instance ${ }^{8}$ and by the Court of Appeal of Gent concerning the complete environmental case law from 2003 till 2007 (see Billiet et al. 2009a, b, c). Thus, we collected 1,034 sentences of courts of first instance and 122 sentences of the court of appeal. In total, 1,882 defendants are tried in these 1,156 criminal prosecutions: 1,617 in first instance and 265 in appeal. It is also interesting to note that $80 \%$ of the defendants are individuals, while only $20 \%$ are legal entities.

In first instance, judges convict three in four defendants. Moreover, one in eight defendants are acquitted, while the remaining defendants are confronted with a postponement of the verdict. ${ }^{9}$ The judges in appeal convict a similar fraction of the defendants (three in four), but appear to acquit more defendants (one in six).

If we turn to the type of sanctions that are imposed by the courts, we see that the monetary fine is by far the most important criminal sanctioning instrument used and is imposed in over $95 \%$ of the convictions. For legal entities, the fines-including additional charges ('opdeciemen') - amount to an average 14,569 euro in first instance and 10,733 euro in appeal. For individuals, the average fines are

\footnotetext{
7 Data are collected within the SBO-project "Environmental law enforcement: A comparison of practice in the criminal and administrative tracks" (2007-2011). More information can be found on the website www.environmental-lawforce.be.

${ }^{8}$ Data for each individual offender are collected in Brugge, Dendermonde, Gent, Ieper, Kortrijk, Oudenaarde and Veurne. Thus we collected data for seven out of the thirteen first instance districts in Flanders. All appeals at these seven courts are dealt with by the Court of Appeal in Gent, one of the five Belgian courts of appeal.

9 Note that the postponement of a verdict implies that the facts of the offending act are proven for that particular offender, but that the favour of postponement is awarded to the offender on condition that there is no recidivism within a certain period.
} 
Table 3 Criminal sanctions (Individuals)

\begin{tabular}{lcrrr}
\hline Criminal sanctions & First instance & \multicolumn{3}{c}{ Appeal } \\
\hline Only fine & 895 & $87.49 \%$ & 117 & $82.40 \%$ \\
Only prison sentence & 1 & $0.10 \%$ & 3 & $2.11 \%$ \\
Prison sentence and fine & 102 & $9.97 \%$ & 18 & $12.68 \%$ \\
Community service & 17 & $1.66 \%$ & 1 & $0.70 \%$ \\
Other & 8 & $0.78 \%$ & 3 & $2.11 \%$ \\
Total number convictions & 1,023 & & 142 & \\
\hline
\end{tabular}

significantly lower: 3,787 euro in first instance and 8,061 euro in appeal. Moreover, for individuals, it is especially noteworthy that in 10 à $15 \%$ of the convictions a prison sentence (combined with a fine) is imposed (see Table 3). The average duration of an imposed-but not necessarily executed-prison sentence is 4.4 months in first instance and 6.2 months in appeal.

Looking in more detail at the prison sentences imposed by the criminal courts (see Figs. 1, 2), we observe that the minimal sentence is 15 days (half a month), while the maximal sentence is 24 months. Approximately $90 \%$ of these prison sentences do not exceed 6 months. Since prison sentences are as a rule combined with fines, it is interesting to look at the average fine level for defendants receiving both sanctions and to compare it with the average fine level for all convicted individuals. Thus we find that the average fine imposed jointly with a prison sentence is 21,133 euro in first instance and 8,128 euro in appeal. These fine levels are substantially higher than the average fine imposed on all convicted individuals in first instance (3,787 euro) and approximately similar to the average fine in appeal (8,061 euro).

Looking at the type of offenders that received a prison sentence, we find that in first instance half of them committed the offense in their professional capacity and half of them committed the environmental offense during their private activities. For appeal, we only find one defendant who committed the offense in his private capacity and all the others were prosecuted in their professional capacity. Next we look at the type of accusations ${ }^{10}$ for which the offenders were convicted with a prison sentence by the courts of first instance (see Table 4). We compare the characteristics of the accusations with those related to all offenders that were criminally prosecuted (Billiet et al. 2011). We find that offenders committing offenses that are damaging the public of private health (e.g. noise violations causing illness among neighbors or soil contamination leading to increased exposure to heavy metals) or committing priority offenses ${ }^{11}$ are more likely to receive a prison sentence. On the contrary, offenders who take positive actions to limit the damage

\footnotetext{
${ }^{10}$ On average one offender was prosecuted for 2.1 proven accusations. This is exactly the same average as for all offenders that were criminally prosecuted.

${ }^{11}$ An offense classifies as a priority offense based on a memorandum drafted by the Council of Prosecutors-General. Some $23 \%$ of the offenders committed at least one priority offense according to the verdicts in first instance in our dataset. Priority offenses include exploiting an installation without the appropriated environmental permit or the illegal disposal of hazardous waste.
} 


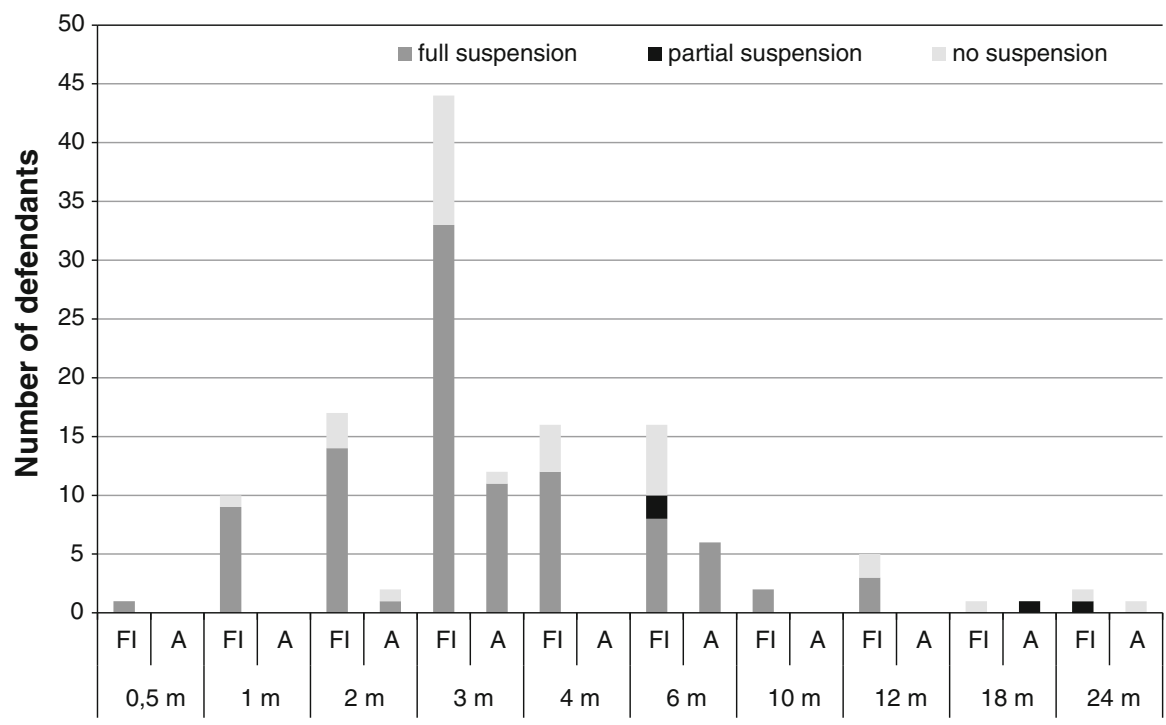

Fig. 1 Suspension of prison sentences (FI first instance, $A$ appeal, $m$ months)

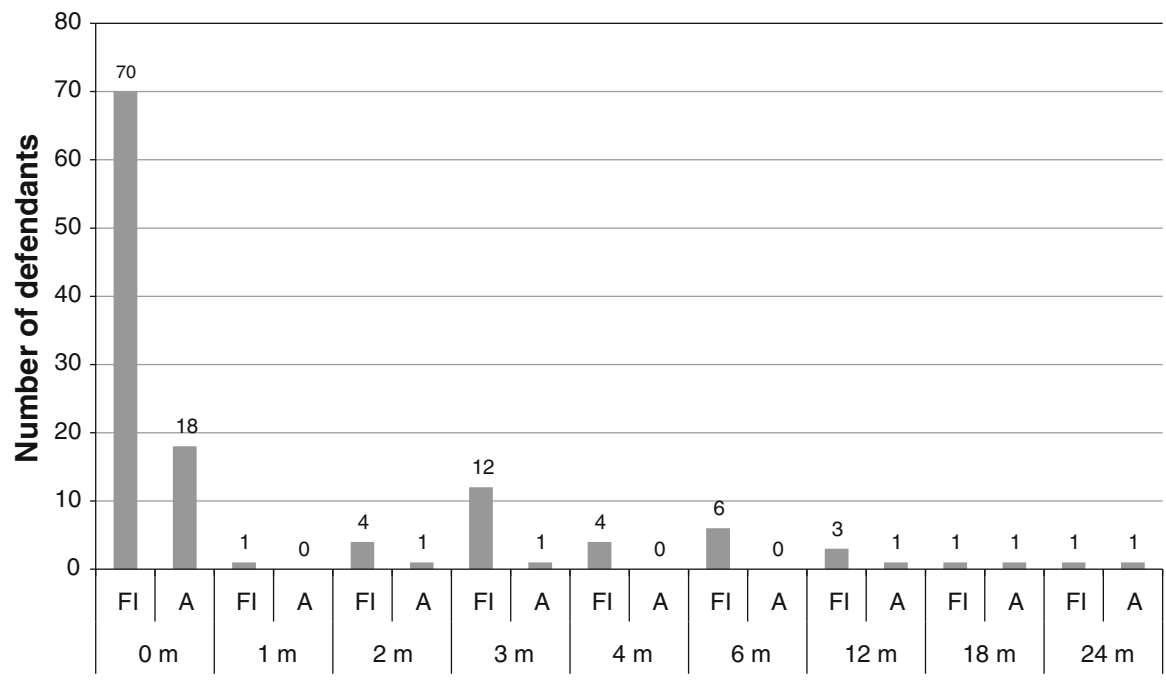

Fig. 2 Effective prison sentences ( $F I$ first instance, $A$ appeal, $m$ months)

caused by the offense are less likely to receive a prison sentence. Finally the type of environmental problem (waste, noise of soil contamination) does not seem to matter.

Further we observe that in first instance (appeal) 66 (76)\% of the sentences are completely suspended and another $3(5) \%$ are partially suspended (see Fig. 1). This seriously reduces the duration of the effective prison sentences, as shown in Fig. 2, 
Table 4 Type of offenses in first instance

\begin{tabular}{lcl}
\hline & $\begin{array}{l}\% \text { of proven accusations } \\
\text { for offenders punished } \\
\text { with a prison sentence }(\%)\end{array}$ & $\begin{array}{l}\text { \% of proven accusations } \\
\text { for all offenders that were } \\
\text { criminally prosecuted } \\
\text { (source: Billiet et al. 2011) (\%) }\end{array}$ \\
\hline Offense damaging to (public) health & 26 & 8 \\
Priority offenses & 54 & 23 \\
Offenses damaging to nature & 4.8 & 3.6 \\
Offender took positive action & 10 & 23 \\
to limit damage caused by offense & 47 & 52 \\
Waste related offense & 21 & 18 \\
Noise related offense & 9 & 11 \\
Soil related offense & & \\
\hline
\end{tabular}

and the average effective prison sentence is only 1.8 months (compared to 4.4 months) in first instance and 2.8 months (compared to 6.2 months) in appeal. In Belgian criminal law, the suspension of a sentence can be accorded to a convict in all but the most serious cases (e.g. not to offenders with an earlier prison sentence of more than 12 months). Execution of the sentence is suspended by minimally one year and maximally three (a.o. prison sentences up to 6 months) or 5 (prison sentences over 6 months) years. The suspension has to be withdrawn whenever the convicted person receives a new verdict containing an effective prison sentence of more than 6 months. It can be withdrawn after a new conviction containing an effective prison sentence from one to 6 months and whenever potentially applicable probation conditions are infringed. ${ }^{12}$ Thus, the frequent practice of imposing suspended prison sentences illustrates the 'carrot and stick' approach used by the courts. In order to prevent repeat offenses, the offender is rewarded by a relatively low sanction for the current offense ('carrot'), but is threatened by a more severe sanction when a repeat offense should occur ('stick').

However, in order to fully understand the sanctioning practice, it is crucial to incorporate the regulator's policy concerning the execution of sanctions that are imposed by courts. Here we must point to the Belgian practice, regulated by directives of the Minister of Justice, of not implementing 'short' prison sentences (Van den Wyngaert 2009). Until January 2005, a 'short' prison sentence was an effective prison sentence of maximum 4 months (De Clercq 2002); since January 2005 it is an effective prison sentence of maximum 6 months (De Clercq 2005). As a rule, 'short' effective prison sentences are not executed. Exceptions, however, are made. Environmental crime used to be one of those exceptions under the older directive. Up to January 2005, 'short' effective prison sentences inflicted for environmental crimes did get some execution, even if only partially. Effective sentences of less than 4 months usually implied some 15 days in jail for the offender (De Clercq 2002). Since February 1st 2005, no exception is made anymore for environmental crime (De Clercq 2005) and 'short' prison sentences, i.e. effective

\footnotetext{
12 Art. 8 and 14 Law 29 June 1964 relative to the suspension, postponement and probation.
} 
prison sentences up to 6 months, are not executed at all. ${ }^{13}$ Moreover, effective prison sentences from 6 months to maximum 3 years are only partially executed. ${ }^{14}$ A prison sentence from 6 to 7 months effective means de facto one month in jail. A sentence from 7 to 8 months effective stands for 2 months. Eight months up to one year effective bring 3 months of seclusion. Sentences from one year up to 3 years effective are reduced to one-third. ${ }^{15}$ Van den Wyngaert (2009) notes that it is difficult to assess whether or not judges are influenced by this practice in their sentencing decisions. As the directives are not published and no reports are published about their application, most judges would be poorly informed about the directives' existence and working. Lack of transparency about sanctioning practices is particularly important in the environmental context, since the regulated community often believes itself subject to unjustifiably harsh criminal sanctions for low-culpability violations (O'Hear 2004). Even when all low-culpability offenders receive probationary sentences, there still may be real delegitimation, demoralization, and overdeterrence costs if the regulated community perceives a substantial risk of imprisonment for accidental or purely technical violations. However, in more recent years, the lack of execution of prison sentences up to 3 years effective due to insufficient place in prison facilities has been extensively covered in the Belgian media. Therefore, judges as well as the general public are well aware of the criminal justice system's failure to execute imposed prison sentences.

\section{Policy issues and concluding remarks}

We can now discuss whether prison sentences for environmental crime are used in practice, how they are used and whether they imply a real threat to violators.

Firstly, looking at the empirical evidence, we see that prison sentences are indeed used in practice as a sanction for environmental crime. For instance, in Flanders some $10 \%$ of verdicts included a prison sentence, while in the US some $30 \%$ of criminal sentences include a prison sentence. The most frequently imposed criminal sanction is however the fine: the available evidence shows that over $90 \%$ of sentenced offenders have to pay a fine. The observation that prison sentences seem to be imposed more often in criminal cases in the US than in Europe can be easily explained by the type of cases that are actually brought to court. The US system relies heavily on administrative and civil sanctions and only uses criminal prosecution for more serious cases. The different studies for Europe, on the other hand, seem to suggest that environmental offenses are on average more likely to be minor offenses and that offenders are often first-time offenders. Overall, the more infrequent use of prison sentences is consistent with the concept of the enforcement pyramid discussed in this contribution.

\footnotetext{
${ }^{13}$ See Directive nr. 1771 of the federal Minister of Justice of 17 January 2005.

${ }^{14}$ See the same directive.

15 Directive nr. 1771 of the federal Minister of Justice of 17 January 2005.
} 
Secondly, we find evidence that prison sentences are rarely imposed as the only sanction, but that they are generally combined with other sanctions such as fines or community services. Also, prison sentences are not always executed, but are often used as a suspended or probationary sanction. In general, empirical evidence on the separate or combined use of prison sentences as well as on the choice between effective or suspended imposition of these sentences remains scarce. Thus additional studies providing evidence for countries that are using different sanctioning approaches would be very valuable. Moreover, there seems to be a misalignment between theory and practice since theoretical models study in general effective prison sentences as a single sanctioning instrument, while in practice prison sentences are often combined with other instruments or used as a suspended sanction. Therefore, it might be worthwhile to explicitly include these different dimensions in the models analyzing the role of prison sentences as a sanctioning instrument.

Finally, we comment on the credibility of the threat of imprisonment for environmental offenders. If models such as the enforcement pyramid are a faithful representation of reality, the Belgian practice of suspending the execution of prison sentences combined with the policy of non-execution of 'short' effective sentences seems to be a dangerous evolution. Crucial to the effectiveness of the enforcement pyramid is the credibility of the threat that, when a violator does not comply when 'asked nicely', this will result in harsher penalties. If the threat of harsher punishment is no longer credible, the whole pyramid can collapse and deterrence can decrease substantially. So, even though harsh punishments such as actually executing prison sentences do not have to occur frequently, the threat of execution should remain credible. Thus, effective prison sentences should be implemented occasionally in order to have a deterrence effect on potential violators. On the other hand, the practice of suspension and probation aims at inducing future compliance and by delaying execution of past sentences rewards past offenders who now comply with the rules. So, if the threat of executing sentences when past offenders again violate the rules is no longer credible, the motivation behind the suspension policy no longer holds and recidivism is no longer discouraged. Unfortunately, we have no data on the evolution in compliance levels for environmental regulation in Flanders and thus we cannot test the impact of the current enforcement practice. If compliance levels remain constant, alternative explanations should be considered. One possibility would be that the stigma effect associated with an imposed-but not implemented-prison sentence is still sufficiently large to serve as a credible harsh threat to would-be environmental violators. Especially for white-collar offenders this might be a plausible assumption. A second explanation would be the presence of social norms. Individuals often comply with unwritten social norms out of a sense of duty or based on ethical and moral considerations. Thus, voluntary compliance with environmental regulations is frequently observed in practice.

We can conclude that according to current law and economic models prison sentences are needed for a variety of reasons such as deterring offenders with limited resources, but also increasing the effectiveness of less severe but cheaper sanctioning instruments. Thus if it is important to maintain the effectiveness of prison sentences as an ultimate threat, it is necessary to guard the use of this 
instrument in practice. After all, the effectiveness of soft enforcement instruments such as settlements and warnings largely depends on the presence of such an ultimate threat. Moreover, the empirical evidence might also indicate a need to extend or adapt the models used in the law and economic literature to include the fact that prison sentence are not only rarely imposed, but that they are rarely executed as well.

Acknowledgments We would like to thank the Strategic Basic Research program of the Institute of Science and Technology for the financial support provided during the research project 060034 (www. environmental-lawforce.be). Moreover we would like to thank Michael Faure for his useful comments on a previous version of the text.

\section{References}

ALRC-Australian Law Reform Commission. (2002). Securing compliance: Civil and administrative penalties in federal regulation. Discussion paper 65. www.austlii.edu.au/au/other/alrc/publications/ $\mathrm{dp} / 65 /$.

Avio, K. L. (1998). The economics of prisons. European Journal of Law and Economics, 6, 143-175.

Ayres, I., \& Braithwaite, J. (1995). Responsive regulation: Transcending the deregulation debate. Oxford UK: Oxford University Press.

Billiet, C. M., Blondiau, T., \& Rousseau, S. (2011). Milieucriminaliteit in het beleid van de strafrechter: Bestraffen tussen Haus en Brundtland. Rechtskundig Weekblad, 74(22), 898-931.

Billiet, C. M., \& Rousseau, S. (2005). Zachte rechtshandhaving in het bestuurlijke handhavingsspoor: De inspectiebeslissing en het voortraject van bestuurlijke sancties. Een rechtseconomische analyse. Tijdschrift voor Milieurecht, 14(1), 2-33.

Billiet, C. M., Rousseau, S., Balcaen, A., Meeus, R., Styns, K., De Meyer, G., et al. (2009a). Milieucriminaliteit in handen van strafrechters en beboetingsambtenaren: Feiten uit Vlaanderen en Brussel. Milieu \& Recht, 36(6), 342-349.

Billiet, C. M., Rousseau, S., Balcaen, A., Meeus, R., Styns, K., De Meyer, G., et al. (2009b). Milieurechtshandhaving: Een databestand voor onderzoek naar de penale en bestuurlijke sanctioneringspraktijk. Tijdschrift voor Milieurecht, 18(2), 128-150.

Billiet, C. M., Vander Beken, T., Rousseau, S., Balcaen, A., Meeus, R., Styns, K., et al. (2009c). Milieucriminaliteit: Feiten omtrent bestraffing. Panopticon, 30(3), 69-75.

Blomberg, A. B., \& Michiels, F. C. M. A. (1997). Handhaven met effect. Een empirisch-juridische studie naar de mogelijkheden voor een effectieve handhaving van het milieurecht's. Gravenhage: VUGA Uitgeverij.

Cherry, T. D. (2001). Financial penalties as an alternative criminal sanction: Evidence from panel data. Atlantic Economic Journal, 29(4), 450-458.

Chu, C. Y. C., \& Jiang, N. (1993). Are fines more efficient than imprisonment? Journal of Public Economics, 51, 391-413.

Chu, C. Y. C., Sheng-cheng, H., \& Huang, T. (2000). Punishing repeat offenders more severely. International Review of Law and Economics, 20(1), 127-140.

Cohen, M. A. (1992). Environmental crime and punishment: Legal/economic theory and empirical evidence on enforcement of federal environmental statutes. Journal of Criminal Law and Criminology, 82(3), 1054-1108.

Cooter, R., \& Ulen, T. (2008). Law \& economics. International Edition. Pearson. p. 582.

Dasgupta, S., Hettige, H., \& Wheeler, D. (2000). What improves environmental compliance? Evidence from Mexican industry. Journal of Environmental Economics and Management, 39(1), 39-66.

De Clercq, J. (2002). Uitvoering van vonnissen en arresten inzake ruimtelijke ordening, leefmilieu en natuurbehoud in al zijn aspecten. In J. van Den Berghe (Ed.), De handhaving van het milieurecht. Kluwer Uitgevers: Mechelen.

De Clercq, J. (2005). Over de uitvoering van vonnissen en arresten inzake milieustrafrecht. FOD Justitie-Opleiding Rechterlijke Orde, Grondige opleiding milieurecht, p. 39. 
Emons, W. (2003). A note on the optimal punishment for repeat offenders. International Review of Law and Economics, 23, 253-259.

Emons, W. (2007). Escalating penalties for repeat offenders. International Review of Law and Economics, 27, 170-178.

Environmental Agency. (2008). Spotlight on business. 10 years of improving the environment. www. environment-agency.gov.uk.

Environmental Audit Committee. (2003). Environmental crime and the courts. UK House of Commons.

Faure, M., \& Heine, G. (2005). Criminal enforcement of environmental law in the European Union. London: Kluwer Law International.

Firestone, J. (2003). Enforcement of pollution laws and regulations: An analysis of forum choice. Harvard Environmental Law Review, 27, 105-176.

Garoupa, N., \& Klerman, D. (2004). Corruption and the optimal use of nonmonetary sanctions. International Review of Law and Economics, 24, 219-225.

Gray, W. B., \& Shimshack, J. P. (2011, in press). The effectiveness of environmental monitoring and enforcement: A review of the empirical evidence. Review of Environmental Economics and Policy.

Heyes, A. (1998). Making things stick: Enforcement and compliance. Oxford Review of Economic Policy, 14(4), 50-63.

Kaplow, L. (1990). A note on the optimal use of nonmonetary sanctions. Journal of Public Economics, $42,245-247$.

Kennedy, J. E. (2002). Making the crime fit the punishment. Emory Law Journal, 51, 753-838.

Levitt, S. D. (1997). Incentive compatibility constraints as an explanation for the use of prison sentences instead of fines. International Review of Law and Economics, 17, 179-192.

Nagin, D., \& Waldfogel, J. (1995). The effects of criminality and conviction on the labor market status of young British offenders. International Review of Law and Economics, 15(1), 109-126.

Ogus, A., \& Abbot, C. (2002). Pollution and penalties. In T. Swanson (Ed.), An introduction to the law and economics of environmental policy: Issues in institutional design (pp. 493-516). Amsterdam: Elsevier.

O'Hear, M. M. (2004). Sentencing the green-collar offender: Punishment, culpability, and environmental crime. The Journal of Criminal Law and Criminology, 95(1), 133-276.

Polinsky, A. M. (2006). The optimal use of fines and imprisonment when wealth is unobservable. Journal of Public Economics, 90, 823-835.

Polinsky, A. M., \& Rubinfeld, D. L. (1991). A model of optimal fines for repeat offenders. Journal of Public Economics, 46, 291-306.

Polinsky, A. M., \& Shavell, S. (1984). The optimal use of fines and imprisonment. Journal of Public Economics, 24, 89-99.

Schnittker, J., \& John, A. (2007). Enduring stigma: The long term effects of incarceration of health. Journal of Health and Social Behavior, 48, 115-130.

Scottish government. (2008). Statistical bulletin crime and justice series: Prison statistics Scotland, 2007/08.

Shavell, S. (1985). Criminal law and the optimal use of nonmonetary sanctions as a deterrent. Columbia Law Review, 85, 1232-1262.

Shavell, S. (1987). The optimal use of nonmonetary sanctions as a deterrent. American Economic Review, 77(4), 584-592.

The Economist. (2010). Criminal justice: Glorious failures, 13 August 2010.

Van den Wyngaert, C. (2009). Strafrecht, strafprocesrecht and internationaal strafrecht in hoofdlijnen. Apeldoorn, Maklu: Antwerpen.

Waldfogel, J. (1994). The effect of criminal conviction on income and trust 'Reposed in the workmen'. Journal of Human Resources, 29(1), 62-81.

WODC-CBS. (2009). Criminaliteit en rechtshandhaving 2008. Ontwikkelingen en samenhangen. Boom Juridische Uitgevers. www.wodc.nl. 